\title{
Writing as resistance in an age of demagoguery
}

\author{
Christian W. Chun \\ University of Massachusetts Boston
}

\section{Introduction}

Writing has long been regarded as an act of overt or covert resistance, depending on the contexts in which writers have questioned and challenged those in power and the means, both materially and discursively, by which they have exercised that power. These written acts of resistance have utilized a variety of genres ranging from outright attacks on the ruling classes in the form of political demands and public pronouncements to more subtle critiques of society in essays, novels, and poetry. In contrast to the written texts that openly called for radical societal changes in famous and widely-disseminated manifestos and declarations, some written acts of resistance at times have had to dissimulate their intentions and aims in order to 'fly under the radar.' While openly critical manifestos aimed to interpellate or 'hail' (Althusser, 1971) their intended addresses in a direct call for action, (e.g., Marx and Engels' The Communist Manifesto in 1848), what are the ways in which equally subversive but seemingly more discreet and circumspect texts call for action in their naming of injustice, inequality, and oppression in the domains of race, class, gender, and sexuality? Are the discursive methods and appeals to readers involved similar in these two different approaches, and how has resistance, rebellion, and even revolution been dialogically co-created at different historical junctures? What do written acts of resistance mean today in our current age of neoliberal and increasingly nationalistic demagoguery as it has been enacted in countries

\footnotetext{
Affiliation

Department of Applied Linguistics, University of Massachusetts Boston, McCormack Hall, 4-447, 100 Morrissey Blvd, Boston, MA 02125, USA

Email: christian.chun@umb.edu
} 
such as the US and the UK with the advent of 'Trumpism' and Brexit? What does resistance look like in other national and cultural contexts such as local communal spaces - including classrooms? These are some of the questions we address these in this special issue of Writing and Pedagogy. Its aim is to advance studies that examine how we can engage with, interpret, and indeed teach to our students and the public at large these various written acts of resistance and how they can be used to contest hegemonic discourses.

\section{Resistance in the Interregnum?}

In the wake of the 2016US Presidential election, the recent UK Parliamentary election, and the current street protests in many areas around the world including France, Brazil, and Hong Kong, countless people who strongly identify as 'socially progressive' - defined here as believing in greater economic, racial, and social equality for all, advocating for increased funding for public education, resisting the dismantling of the social-welfare state including public healthcare, and insisting on actual democratic governance in society - are perplexed about why and how right-wing populists such as Donald Trump and Boris Johnson have appealed to significant number of voters in their respective countries. Are these political leaders and others like them just atypical figures in this historical moment or does their emergence signify a new and alarming trend?

During the 1920s in Italy, the philosopher, journalist, and political activist Antonio Gramsci, who was imprisoned by Mussolini for his political activities, described what was happening at the time not only in his country, but also in Germany with the rise of Nazism, in the following manner:

If the ruling class has lost its consensus, i.e., is no longer 'leading' but only 'dominant', exercising coercive force alone, this means precisely that the great masses have become detached from their traditional ideologies, and no longer believe what they used to believe previously, etc. The crisis consists precisely in the fact that the old is dying and the new cannot be born; in this interregnum a great variety of morbid symptoms appear. (1971:

275-276)

It seems clear to many of us who identify as progressive that we are living in another interregnum in which seemingly morbid signs embodied and enacted by politicians who appear to be ridiculously outlandish and at times, indeed a caricature of what people in democratic countries expect of their elected leaders, are actually indexing as Gramsci astutely pointed out, a crucial historical rupture with the heretofore 'normalized' hegemonic leadership and its discourses. These normalized hegemonic discourses are 
best illustrated by neoliberal politicians who claimed the mantle of 'progressive' politics, such as US President Barack Obama and UK Prime Minister Tony Blair. Yet, not only did both oversee the continuing privatization and dismantlement of the social-welfare state, they also (particularly Obama) continued the global wars supporting Western imperialist dominance. In addition, the relative decline of the US and UK economies, with the continued outsourcing of jobs, particularly in the manufacturing sector, led to some voters in the US who had previously supported President Obama and the Democratic Party and those in the UK who had always voted Labour to switch their allegiances to the opposing political parties - the Republicans led by Trump, and the Tories under Johnson. But was it only the loss of jobs and ensuing economic insecurity and anxieties that prompted these voters to support and indeed embrace the rise of these right-wing populists?

Drawing on a Gramscian perspective, Stuart Hall (1988) analyzed the rise of Margaret Thatcher during the 1980s and offered an analysis that featured a now eerily prophetic campaign slogan:

When, in a crisis, the traditional alignments are disrupted, it is possible, on the very ground of this break, to construct the people into a populist political subject: with, not against, the power bloc; in alliance with new political forces in a great national crusade to "make Britain "Great" once more'. (p. 49)

This hegemonic co-construction of the people - and actually the question that should be asked is: which people are we talking about? - into a rightwing populist subject that supports the powers that be does indeed rely on a key ideological discursive dimension - that of nationalism, as indexed by political leaders promising to make their countries 'great' again. However, exactly what is involved with making a country great again? Historically it has meant going to war and conquering other nations in the name of 'the people'.

Right-wing populist politicians have also claimed a certain ideologicallyframed nostalgic longing for a largely fictionalized past in which a specified and named people are accorded the singularized sole identity of the nation. This "kind of doleful nostalgia for an unrealizable "paradise lost" that is perhaps no less debilitating or distorting than ideology itself' (Gardiner, 1992: 27) has an extremely effective and affective appeal to those who loudly bemoan their loss of status of 'who we are in these times'. This has a dual function - the first is that this discursive construction of a 'conservative utopia is characterized by an ideological appeal to an idealized and mythologized past which de-legitimates any challenge to the reigning social order' (ibid: 32 ), thereby shunting aside any legitimate dissent and grievances among those suffering from economic anxieties stemming 
from job loss and declining living standards. This results in a racializing discourse of seeming 'unity' amongst the targeted construction of a certain populace, which then turns the focus away from the political and social order of the elites to an ideologically invented adversary.

This leads to the second function that acts in tandem with the discursive co-construction of a particular 'people' set against 'Other' people as the imaginary adversary in the way of their attempts to achieve a better life. This accordance of a specific nationalistic identity necessarily involves other discursive domains that have been crucial to the remaking of (some) people into a new populist subject. In the contexts of the US and UK at least, these also involve the interconnected racializing discourses involved in a nationalistic one of naming the 'Other' as being the threatening and dangerous adversary of the people. This 'Other' has taken on various forms, such as 'the (undocumented) immigrant' sneaking into the country with the purpose of stealing jobs from local people, 'the refugee' living off the State at taxpayer expense, 'the foreign religious zealot' who refuses to integrate into and adopt the dominant cultural traditions of the nation (however these traditions and practices are defined), 'the anti-patriot' who only has contempt for their country in displaying lack of gratitude for what it has done for them, and 'the welfare queen' (coined by Ronald Reagan's speechwriters) who sponges off the government for free handouts such as unemployment allowances and free healthcare. These ideologically fictionalized adversaries fulfill the core aim of any right-wing populist movement in naming the 'adversary' for the(ir) people to combat.

And yet, would any other adversary be accurate in terms of who actually does harm to many people? Naming such an adversary necessitates going beyond the rationalistic discourse often used by liberal politicians in attempting to appeal to people who are upset by the aforementioned adversaries. Any written form of resistance to hegemonic orders would need to address the affective dynamics of people who are angry, upset, $\mathrm{sad}$, and broken. One critique of those on the left - ranging from progressives to radicals - is that they do 'not see that it is possible to connect with the ordinary feelings and experiences which people have in their everyday lives, and yet to articulate them progressively to a more advanced, modern form of consciousness' (Hall, 1988: 170-171). In not understanding 'the necessarily contradictory nature of human subjects, of social identities' and the accompanying 'politics as a production' (ibid: 170), those 'in the know' have time and time again dismissed those 'who don't know' or 'don't want to know'

Thus any resistance to social oppression and economic injustice, in trying to appeal to and connect with people who blame 'the Other(s)', must be rooted in the affective. I would argue that people who only follow right-wing 
supported media such as Fox News in the US and the Daily Telegraph and Daily Express in the UK are fulfilling their emotional needs (in this context, anger and frustration at the world) which often supersede any rationalist discourses. These complex and contradictory emotions are rooted in our everyday alienation, or as more accurately termed, 'estrangement' (Marx, 1844) from both society at large and on a micro-scale. Our sense of being estranged can take many forms, be it from our workplace with fellow workers and the bosses, the community and our neighbors who we may barely know, our classmates and teachers in schools, and importantly, our sense of self (or lack thereof) in the roles in society we are supposed to be enacting and also in our being positioned by others in constructed roles we may not always accept as aligned with our own self-identifications. I maintain that these emotional and affective needs are often greater (or at the very least, as equally important) than our intellectual and rational needs in making sense of the world(s) we live in. So perhaps we can only be open to rationalist discourses appealing to our reasoning when our emotional needs are met? 'You're not going to win any arguments' - is it only all about emotion? Is it either/or, though? Can intellectual and rationalist discourse work in dynamic tandem with affect and estrangement?

\section{Resistance and the Discursive Dynamic between Thinking and Feeling}

Is 'much of modern social reality ... illegible to the people trying to make sense of it' (Sennett, 2006: 12)? Based on his ethnographic research conducting interviews with US workers in the 1990s, Sennett (2006) argued that many people 'need a sustaining life narrative' in that 'they take pride in being good at something specific, and they value the experiences they've lived through' (p. 5). These life narratives we tell ourselves to sustain our sense of worth are based in part on our notions of 'rationalized time' - that is, how we think time should be accorded to the spaces of work and home. For example, if we have a job that begins at $9 \mathrm{am}$ and ends at $5 \mathrm{pm}$, our rationalized time-frame would have this work be only eight hours long at the most, aligning with the aforementioned start and end. Yet in this digital age in conjunction with the now neoliberal and corporatized discourses of 'best practices' and 'outputs' adopted by universities with endless work emails and texts, this work time does not stop at an appointed hour. This former sense of rationalized time 'enabled people to think about their lives as narratives - narratives not so much of what necessarily will happen as of how things should happen' (ibid: 23, emphasis added). How we articulate what and how things should happen in our lives, and why they do not are 
part and parcel of not only how we view our society and world, but also how these articulations help feed into our emotions on a daily level.

The British literary critic F. R. Leavis, in writing about his contemporary critic Joseph Krutch, quoted Krutch's definition of common sense as the 'acceptance of certain current assumptions, traditions and standards of value which are never called into question because to question any of them might be to necessitate a revision of government, society and private conduct more thoroughgoing than anyone liked to contemplate' (Leavis, 1962, as cited by Eagleton, 1996: 71). However, this stance ignores the varying shifts in our common sense due to historical periods of upheaval and change, something that is a fundamental characteristic of the socioeconomic system known as capitalism. Gramsci (1971) had a much more nuanced view of what constitutes 'common sense'. From his perspective, our philosophizing about society, the world, the social relations therein, and how they affect our everyday lives is not the sole sphere of influence of those he called 'traditional intellectuals'; i.e., scholars, intellectuals, and journalists. It is also the sphere of influence of the discursive and materialized practices of 'common' everyday people, inasmuch as 'everyone is a philosopher' (p. 323).

Gramsci (1971) categorized what he called this 'spontaneous philosophy' of everyday people, or as he called them, 'organic intellectuals', as comprising the following three realms: (1) language, 'which is a totality of determined notions and concepts'; (2) popular religion including folklore beliefs, superstitions, and opinions; and (3) common sense and good sense (p. 323). Gramsci, who had studied linguistics at the University of Turin, took a keen interest in how we use language to co-construct discourses of common and good sense. His view of these discourses is aligned with the notion that 'the use of language in social interaction ... (is) to accomplish some action in the social world' (Scollon and Scollon, 2004: 2). This dynamic use of language and action via social interactions included, as Gramsci pointed out, the affective domain of popular religion, which has always addressed not only the spiritual needs of people, but also importantly, the emotional needs that have been largely unmet in the alienating hierarchical-based societies of feudalism and capitalism.

The English translation of Gramsci's 'senso commune' into 'common sense' is a bit misleading in that what he meant by common sense is the commonly shared ways in which we hold and articulate the at-times inconsistent and incongruous views of the world. As Hall and O'Shea (2013) defined this idea of common sense, it is 'a form of "everyday thinking" which offers us frameworks of meaning with which to make sense of the world' (p. 8). Although these views may be ideologically contradictory as seen by some, nevertheless, 'how things are talked about is one of the major 
processes by which our worlds are constructed, legitimated, ratified, contested' (Scollon and Scollon, 2004: 9). And since 'the broader social issues are ultimately grounded in the micro-actions of social interaction and, conversely, the most mundane of micro-actions are nexus through which the largest cycles of social organization and activity circulate' (ibid: 8), it is crucial to address and analyze the ways in which social interactions on an everyday basis enact and disseminate the hegemonic discourses in mediated circulation.

Thus, for any philosophy of praxis or critical engagement with these socialized micro-actions to occur, 'the starting point must always be that common sense, which is the spontaneous philosophy of the multitude' (Gramsci, 1971: 421). Thus, he argued:

For a mass of people to be led to think coherently and in the same coherent fashion about the real present world, is a 'philosophical' event far more important and 'original' than the discovery by some philosophical 'genius' of a truth which remains the property of small groups of intellectuals.

(Gramsci, 2000: 327)

From this perspective, Gramsci's advocacy of an engagement with how everyday people co-construct their world views 'represents simultaneously the valorization and sublation' of common sense, which is 'recognized as both the necessary starting point of critical philosophical activity (as the incoherent ensemble of conceptions of the world really operative among the subaltern social groups, expressing and confirming the experience of subalternity), and because of this, as 'one of the obstacles that must be overcome if the subaltern groups are ever to build their own hegemonic project - that is, to exit from the condition of subalternity' (Thomas, 2015: 108). So how do we develop and co-construct counter-hegemonic discursive framings to think coherently and critically about the real present world? Indeed, as Fontana (2002) noted, 'it is a problem that combines political, epistemological, and educational spheres of activity' (pp. 27-28).

It is important to note here that Gramsci's notion of people's common sense is much more complex than the idea of false consciousness in that it is a constantly fluid and dynamic formation comprising factual truths at times with misleading misrepresentations (Forgacs, 2000). At this very core of common sense though, according to Gramsci (1971), is a 'healthy nucleus ... the part of it which can be called "good sense" and which deserves to be made more unitary and coherent' (p. 328). As he argued, 'it appears that here again it is not possible to separate what is known as "scientific" philosophy from the common and popular philosophy which is only a fragmentary collection of ideas and opinions' (p. 328), and thus common sense is 'a chaotic aggregate of disparate conceptions, and one 
can find there anything that one likes' (p. 422). Moreover it is important to remember that common sense is not a single unique conception, identical in time and space' (p. 419). Rather, it is 'the "folklore" of philosophy, and, like folklore, it takes countless different forms' and therefore is 'fragmentary, incoherent and inconsequential, in conformity with the social and cultural position of those masses whose philosophy it is' (p. 419). Importantly, as Green and Ives (2009) noted, 'the contradictory nature of common sense is not the product of some sort of intellectual or psychological deficiency on the part of the masses' (p. 23). The various contradictions of everyday people's common sense are rooted in the ongoing 'ensemble of social relations, economic exploitation and the various exclusions they produce and reproduce' (p. 23). Indeed, it is not only the so-called 'masses' that have this 'common sense', but it is also the traditional intellectuals themselves who propagate their own version of common sense. Thus, 'for Gramsci the messy conglomerate that is common sense - precisely because it is not any kind of systematic whole - must be teased apart and its separate elements analysed' (Crehan, 2011: 283). This is done with the aim of 'bringing into being of new, genuinely counter-hegemonic narratives' which has to 'start with the world inhabited by the mass of the population ... that world is the world of common sense' (p. 283).

Although it is thus important that 'in order to have an impact on common sense it is necessary to occupy a position "within the field of common sense"' (Liguori, 2009: 124), again, the affective discursive domains of people need to be engaged with, before the rationalistic and reasoning approaches. Seen in this manner, common sense is not simply an enemy to be defeated' but instead 'a dialectical and maieutic relationship has to be established with common sense in order to transform it (and enable to transform itself) so that a "new common sense" will prevail - a crucial achievement in the struggle for hegemony' (ibid: 124). Gramsci's (1971) important methodological claim was for any critical approach to be in the form of perpetual struggle' in which 'the starting point must always be that common sense which is the spontaneous philosophy of the multitude and which has to be made ideologically coherent' (p. 421).

And yet, within the numerous discursive and materialized (spoken, written, online, and so forth) spaces and spheres of civil society, there is always competition and conflict among many since consent is of course never a given but must be learned, taught, organized, generated, and in this manner, 'earned.' The struggles for the consent from the populace has as its primary purpose to 'generate, proliferate, and disseminate a given conception of the world, such that it becomes "historically true", which, in turn, means its transformation into the "commonsense" of the people' (Fontana, 2008: 96). Hegemony is therefore co-constructed and upheld in these 
spheres of civil society through intellectuals aiding in the "transformation of philosophy and knowledge into the commonsense of the people; in turn, such a transformation is simultaneously the organization and proliferation of consent' (ibid: 96). And as Fontana (2008) observed, this struggle over competing and opposing conceptions and representations of the world is indeed the fundamental core of Gramsci's view of hegemony and forms the basis of his whole theoretical and political project. Importantly, the Gramscian construct of hegemony involves not the coercion, but the consent of people. This consent is based on co-constructing the appeal to their everyday needs through ideologically affective framings. Thus the counterhegemonic struggle has to address these very emotional arguments that are rooted in people's lived realities but are not always in accordance to an 'objective' reality. Indeed, Gramsci (2000) acknowledged as much:

The philosophy of praxis can exert a leverage on people's consciousness because a part of that consciousness is already aware of its truth. It thus draws out and elaborates that which people already 'feel' but do not 'know', in other words that which is present in nascent or inchoate form in their consciousness but which is contradicted and immobilized by other conceptions. (p. 323)

\section{Addressing Structures of Feeling as Resistance}

In discussing the important legacy of the literary, cultural, and political critic and scholar Raymond Williams, Eagleton (1996) describes Williams' notion of 'structure of feeling' as 'mediating ... between an historical set of social relations, the general cultural and ideological modes appropriate to them, and the specific forms of subjectivity (embodied not least in artifacts) in which such modes are lived out' (p. 110). Williams (1977) conceptualized his notion of 'structures of feeling' as follows:

The term is difficult, but 'feeling' is chosen to emphasize a distinction from more formal concepts of 'world-view' or 'ideology'. It is not only that we must go beyond formally held and systematic beliefs, though of course we have always to include them. It is that we are concerned with meanings and values as they are actively lived and felt, and the relations between these and formal or systematic beliefs are in practice variable (including historically variable), over a range from formal assent with private dissent to the more nuanced interaction between selected and interpreted beliefs and acted and justified experiences ... We are talking about characteristic elements of impulse, restraint, and tone; specifically affective elements of consciousness and relationships: not feeling against thought, but thought as felt and feeling as thought: practical consciousness of a present kind, in a living and interrelating continuity. We are then defining these elements as a 
'structure': as a set, with specific internal relations, at once interlocking and in tension. (p. 132)

It is important to highlight here again that there does not exist an either/ or binary of so-called rational thinking and our at-times seemingly iirrational' feelings and emotions. Instead, as Williams pointed out, these exist as a dynamic whole, inseparable in the ways in which they inextricably feed into each other and affect the ensuing frames of thought and accompanying emotions. This should be obvious when in any conversation that has led to heated arguments among friends, colleagues, neighbors, or even strangers that deal with the controversial and divisive political events and ideas of our time, that we become more animated and upset when others strongly disagree with our views. And it is precisely these lived feelings that often obstruct any 'rational' counter-arguments from taking hold.

This is illustrated in a recent article that appeared in The Guardian, entitled 'In Blair's old seat, the regulars agree: “Corbyn doesn't understand us here". In interviews with voters in post-industrial northern England which had traditionally voted for the Labour Party, one voter who is 91 years-old told the reporter that Jeremy Corbyn is 'not my kind of man. Not strong enough. He doesn't understand us here' (Adams, 2019). This sentiment is coming from a voter who had voted for Labour in every election since 1945. But in this December 2019 election, for the first time he voted for the Conservative Party of Boris Johnson. Could his framing of Corbyn not being strong enough be seen as perpetuating a certain hetero-masculine discourse that (male) political leaders need to show their 'strength', however defined? Perhaps. Yet another interpretation of this is possible when his following utterance of 'he doesn't understand us here' (emphasis added) is taken into account. It seems evident that these two sentences seen in tandem enact not only this voter's values as actively lived and felt, as Williams (1977) observed, but also the articulated consciousness of one who has felt abandoned and left behind by the New Labour policies (i.e., the conveniently reframed neoliberal continuation of Thatcherism) of Tony Blair. Undeniably, this is the very 'practical consciousness' of his structures of feeling that has led to this voter rejecting his past voting practices.

Our situated role as educators in our classrooms engaging with students who hold opposing views with us and with one another reflects a similar dynamic, what Fontana (1993: 69) calls 'the movement from thinking to feeling, and from feeling to thinking, (which) is a mutual, reciprocal relation that parallels the relation established between the educator and the student'. It is important to note that in any engagement, be in the classroom or via writing that this reciprocal relation 'does not posit a static, mechanical distinction between ethics and politics, thought and action; 
it understands feeling, thinking, seeing, and acting as mutually related and mutually dependent aspects of a totality that is constantly becoming' (ibid: 69).

Learning in the classroom should be seen as a continuing dialogue in which student and teacher enact Bakhtin's $(1981,1986)$ notion of multiple voices and perspectives. The Bakhtinian dialogical perspective is aligned with Gramsci's common and good sense in that there is never a total hegemonic articulation of particular ideological formations (Gramsci, 1971), or as Bakhtin (1986) called it, 'centripetal discourses' because there always exists 'centrifugal discourses' that create conflicting sets of heteroglossic discourses. In this sense, centrifugal discourses are akin to the 'healthy nucleus' of good sense that are within people's common-sense beliefs. Learning spaces in particular are sites in which 'any utterance is a link in a very complexly organized chain of other utterances' (Bakhtin, 1986: 67). It is these utterances that contain traces, or even at times significant passages of other utterances reflecting Gramscian good sense that are worth examining for their social constructions and meanings. Because any utterance 'cannot fail to brush up against thousands of living dialogic threads, woven by socio-ideological consciousness around the given object of an utterance; it cannot fail to become an active participant in social dialogue' (Bakhtin, 1981: 276). In the following section, living dialogic threads are addressed specifically with concrete pedagogical suggestions.

\section{Writing as Maieutic Resistance}

Pedagogical approaches in the classroom have at times relied on the Socratic method of following up on student responses by asking further questions to highlight their presuppositions and assumptions. These critical dialogues can be furthered in writing assignments in which dialogues can be continued not only in the maieutic manner as Socrates proposed, but also in the Bakhtinian sense in which students address how particular words are used at historical junctures, in ideological framings, and discursive mediations that reflect the shifting meanings in specific contexts. This is vital in contesting 'the monologic imagination', which 'often takes the form of denial or dismissal, refusing to take up the other expression in a meaningful way' (Tomlinson, 2017: 3). However, the attempt at a foreclosure of a dialogical response is likely to fail since language use is indeed always dialogical, as Bakhtin (1981) noted. In our everyday use of language and discourse, 'it always constructs an orientational stance toward real or potential interlocutors, and toward the content of what is said' (Lemke, 2002: 72). 
In this current era of nationalistic demagoguery 'when people claim to represent a nation's Geist, speak in the voice of "we, the people", and speak in the voice of God' (Tomlinson, 2017: 3), how one addresses the 'truth' about society and the world can have an impact on learning in the classroom. Thus one approach in the classroom, and in particular, the language classroom is to examine with students how and why words acquire certain meanings. This can be followed by how these meanings are contested and by whom. This approach can prompt further dialogues and reflections on how language is used in discourse. Inasmuch as the word 'is the most sensitive index of social changes, and what is more, of changes still in the process of growth, still without definitive shape and not as yet accommodated into already regularized and fully defined ideological system' (Vološinov, 1973: 19 , emphasis in the original), an examination of particular words can facilitate language learning beyond formalistic approaches in terms of acquiring new vocabulary towards a deeper understanding of how we use language to co-construct hegemonic consent. This knowledge has the potential of course to turn it around as it were, to then use language as resistance in co-constructions of counter-hegemonic dissent.

As Vološinov (1973) argued, 'what is important about the word in this regard is not so much its sign purity as its social ubiquity' (p. 19, emphasis in the original). One example of the social ubiquity of the word is the common omnipresent definition of 'democracy'. This word is used repeatedly by politicians in many Western countries to justify wars in its name. It has also been used in insisting that 'there is no alternative' (in Margaret Thatcher's famous claim) to any other social and economic organization of society. And yet, democracy is understood differently among those who advocate its implementation at the workplace (e.g., Wolff, 2012, 2015), in situating its meaning beyond the time-scale of voting every year or so at the polling booth. This again highlights Vološinov's observation that 'the word is implicated in literally each and every act or contact between people - in collaboration on the job, in ideological exchanges, in the chance contacts of ordinary life, in political relationships, and so on' (1972: 19).

Thus, how we communicate with others is shaped in part by the different contextual usages of the word, and the understandings which are situated in mutual agreement and/or disagreement. But co-constructions and contestations of the meanings of the word form one basis of resistance because they can subvert how monologic speakers attempt to attach an ideologically singular meaning to the word at stake (as in 'democracy'). As Bakhtin (1981) argued, 'each word tastes of the context and contexts in which it has lived its socially charged life; all words and forms are populated by intentions' (p. 293). Several questions can be used as writing prompts for students in examining this language in action: Whose intentions count more 
in specific contexts, and why? How and why are specific words used by individuals in contextual situations? Do these words mean something different in another context? How might some words acquire 'status' in framing an argument on political, social, and economic issues? Why would a word be more valued and accepted by some but not by others? Finally, 'how are specific social meanings conferred a higher social, political, and cultural capital which then become integrated within a social system reproducing existing economic and social hierarchies without any questioning or challenging from some people' (Chun, 2019: 201)?

\section{Resistance in Contexts - Featured Articles in this Issue}

The articles in this special issue explore myriad written acts of resistance in contextualized and culturally-specific spaces, acts that confront and oppose hegemonic discourses seeking to position and essentialize people contrary to their agentive self-identifications. In this manner, the writers described in these articles are 'not only objects of authorial discourse but also subjects of their own directly signifying discourse' (Bakhtin, 1984: 6). These acts of resistance seek to upend the dominant common sense that continues to oppress certain people be it linguistic identity and ideology (Kohls, this issue), the sexualized violence of patriarchy (Bhattacharya and McGovern, this issue), and the insistence of being able to define oneself in different contexts (Iyer, this issue).

In 'Schools, sexual violence, and safety: Adolescent girls and writing resistance at an afterschool program in suburban Mumbai', Usree Bhattacharya and Kathleen R. McGovern address a vital and under-addressed issue - sexual violence toward females in schools and its relationship to their education, academic performance, participation, and interactions in the classroom. This violence extends beyond the immediate classroom (e.g., sexual harassment by teachers and male classmates) and/or the school grounds to the bus transportation to and back from the school that females students need to use. Using a Foucaultian framework, Bhattacharya and McGovern remind us that 'resistance is always a possibility' inasmuch as forms of power and knowledge have always been entwined. Indeed, 'knowledge is not an established body of data and ideas possessed by a culturally superior entity; rather, knowledge is itself the product of the "conversation" (the "rational discourse") between teacher and student' (Fontana, 1993: 151). Drawing on selected female students' essays in an after-school program that not only name the daily threats they face both in and out of school, but also the brutally patriarchal discourses and accompanying practices that position them in ways that enable sexual violence to occur on a daily basis, the authors highlight these writers' agencies in finding and 
creating spaces in which to name the powers that be in society. But their written acts of resistance also importantly insist on their right to exist as equals in their country and to live freely in a world without fearing for their lives on a daily basis. These agentive acts of resistance in writing should be acknowledged and addressed in the classroom with both school assignments and online posts, with a critical focus on literacy practices speaking a much-needed truth to power in these times.

Robert Kohls makes the compelling argument in 'Making sense of resistance in an afterschool tutoring program: Learning from volunteer writing tutors' that resistance 'is not a behavior flaw or a moral failing; it is positive and instrumental to students' intellectual and social development' (Kohls, this issue). In the context of an urban afterschool volunteer tutoring program, Kohls examines how three tutors view what constitutes 'good' writing, their perceptions and impressions of their tutees, as well as the opinions of the tutees themselves towards their tutors. These involve not only learner and teacher identities (e.g., what a 'good' student means in situated learning contexts), but also what constitutes and enacts a cultural and linguistic identity in Canada.

Resistance in a classroom context can manifest itself in students resisting writing assignments and instruction, as well as instructors resisting both the curricula they deem to be unhelpful and even harmful and the students who may appear to be disturbing the class, as Kohls points out. But importantly, resistance in classrooms can be a positive force in that students and teachers can question and challenge their traditional roles as being a one-way street in terms of who is learning and who is teaching. Are students, particularly language learners, merely passive recipients of formalistic grammar and traditional genre literacy? Or can these learners in turn question how and why grammar helps to construct particular meanings and genres perpetuate certain epistemological paradigms?

Sreedhevi Iyer, in 'Will the "real" author please stand up: Flawed discursive self-presentation of Junot Diaz, examines the complex dynamics of 'cultural authenticity' of authors of color, particularly in the current age of neoliberalism in which 'authenticity' has been re-semiotized to mean 'a presumed expectation of capitalistic endeavors and its hierarchical institutions, instead of being critical of such a system' (Iyer, this issue). However, in an author's agentive act of resisting a dominant discourse, one's selfdefining discursive attempts of being an authentic identity necessarily involves 'a dynamic process involving conflict, contestation and reinvention' (Blommart and Varis, 2011: 4, as cited by Iyer, this issue). This is further complicated in the engagement with social media in which any writer faces the conundrums of the written enactments of the presentation of self in the everyday life (Goffman, 1959) now shaped by the algorithmic data of 
online platforms and the (same?) enactments in face-to-face personal and public interactions. These social media performances of the self as it were also call into question the very role of the public intellectual - is the function of the public intellectual to articulate and validate one's critical resistance to the daily oppressions of society? And in doing so, while inhabiting multiple and seemingly contradictory discursive self-positionings, how does any writer 'keep it real' as Diaz points out as an act of resistance?

\section{Reflections on Practice and Book Review}

In 'Writing and identity: Promoting critical discourse amidst double consciousness', Stephanie Gollobin Ventura situates the critical theories of double consciousness, critical language awareness (CLA) and critical discourse in actual pedagogical practices in an adult English language program. Discussing difficult and often-ignored topics such as race and sexuality in the English language learning classroom has the potential to lead to furthering the students' English language literacies in their growing awareness of how language and discourse co-construct common-sense beliefs, perception, and views of socialized and racialized identities. By developing their knowledge of how language and discourse are used in these constructions, students can engage with literacy skills in articulating resistance to oppressive positioning by others.

In his book review of Stray Dogs: Interviews with Working-class Writers, John Lepley comments on the mainstream media's narrow portrayal of working-class voters in the 2016 US Presidential election. He reminds the reader that the working class is not confined to one 'race' - that, is White, nor has it ever been. By highlighting the importance of spaces in which writing and reading were enabled and supported by American unions in the past that helped the rise of progressive political consciousness, Lepley stresses the urgent need for these spaces of literacies to be available for those who lack the cultural capital. This is imperative for any social and economic justice movement will need to comprise all people of the working class for any real change to occur.

\section{Conclusion}

Writing as resistance in an age of demagoguery can no longer be done with the sole aim of 'speaking truth to power' as it were. Those who rule in society already know the truth of their hold on power. Instead, written acts of resistance should also attempt to speak truths to those who are not in power but have been convinced otherwise - e.g., agreeing with Trump 
that mainstream media such as the New York Times is 'fake news' or that wealthy political leaders have the working people's best interests at heart. The articles featured in this special issue offer important insights and pathways to engage on the multiple terrains of people's emotions and lived experiences, and how language and discourse can confirm or deny these. In their concrete examples of everyday resistance, the writers in this issue illuminate the ways in which we can mobilize the healthy nucleus of good sense in people's everyday common-sense beliefs for a socially just world. Importantly, they demonstrate how we can confront hegemonic discourses that would have the word to be uni-accentual, that is, devoid of any other meaning that would challenge it. And in doing so, they remind us that any ideological sign is socially multiaccentual in 'its vitality and dynamism and the capacity for further development' (Vološinov, 1973: 23). Writing as resistance overturns the ideological signs of our times.

\section{About the Author}

Christian Chun is an Associate Professor in the Department of Applied Linguistics, University of Massachusetts Boston.

\section{References}

Adams, T. (15 December, 2019). In Blair's old seat, the regulars agree: 'Corbyn doesn't understand us here'. The Guardian. Retrieved from https://www.theguardian.com/politics/2019/dec/15/blair-old-seat-sedgefieldrejected-corbyn-perceived unpatriotic?CMP=share_btn_fb\&fbclid=IwAR37g wS5SRC1q7ga4bPbauIqh_kEQ6ETWGkvEVtY7-ia5B7WU8u4U_KYgUQ

Althusser, L. (1971). Lenin and Philosophy and Other Essays (B. Brewster, Trans.). New York: Monthly Review Press. (Original work published 1966-1970.)

Bakhtin, M. (1981). The Dialogic Imagination. Austin, TX: University of Texas Press.

Bakhtin, M. M. (1984). Problems of Dostoevsky's Poetics. Minneapolis, MN: University of Minnesota Press. https://doi.org/10.5749/j.ctt22727z1

Bakhtin, M. (1986). The problem of speech genres. In C. Emerson and M. Holquist (Eds), Speech Genres and Other Late Essays, 60-102. Austin, TX: University of Texas Press.

Chun, C. W. (2016). Addressing racialized multicultural discourses in an EAP textbook: Working toward a critical pedagogies approach. TESOL Quarterly, 50(1), 109-131. https://doi.org/10.1002/tesq.216

Chun, C. W. (2019). Methodological issues in critical discourse studies. In J. McKinley and H. Rose (Eds), The Routledge Handbook of Research Methods in Applied Linguistics, 199-210. London: Routledge.

https://doi.org/10.4324/9780367824471-18 
Crehan, K. (2011). Gramsci's concept of common sense: A useful concept for anthropologists? Journal of Modern Italian Studies, 16(2), 273-287. https://doi.org/10.1080/1354571X.2011.542987

Eagleton, T. (1996). The Function of Criticism: From The Spectator to Poststructuralism. London: Verso.

Fontana, B. (1993). Hegemony and Power: On the Relation between Gramsci and Machiavelli. Minnesota, MN: University of Minnesota Press.

Fontana, B. (2002). Hegemony and rhetoric: Political education in Gramsci. In C. Borg, J. Buttigieg, and P. Mayo (Eds), Gramsci and Education, 25-40. Lanham, MD: Rowman \& Littlefield Publishers.

Fontana, B. (2008). Hegemony and power in Gramsci. In R. Howson and K. Smith (Eds), Hegemony: Studies in Consensus and Coercion, 80-106. New York: Routledge.

Forgacs, D. (Ed.). (2000). The Antonio Gramsci Reader: Selected Writings 19161935. New York: New York University Press.

Freire, P. (1970). Pedagogy of the Oppressed. New York: Continuum.

Gardiner, M. (1992). Bakhtin's carnival: Utopia as critique. Utopian Studies, 3(2), 21-49.

Goffman, E. (1959). The Presentation of Self in Everyday Life. New York: Doubleday.

Gramsci, A. (1971). Selections from the Prison Notebooks (Q. Hoare and G. Nowell-Smith, Trans.). New York: International Publishers.

Gramsci, A. (2000). Philosophy, common sense, language and folklore. In D. Forgacs (Ed.), The Antonio Gramsci Reader: Selected Writings, 1916-1935, 323-362. New York: New York University Press.

Green, M. E. and Ives, P. (2009). Subalternity and language: Overcoming the fragmentation of common sense. Historical Materialism, 17, 3-30. https://doi.org/10.1163/156920609X399191

Hall, S. (1988). The Hard Road to renewal: Thatcherism and the Crisis of the Left. London: Verso.

Hall, S. and O'Shea, A. (2013). Common-sense neoliberalism. Soundings, 55, 8-24. https://doi.org/10.3898/136266213806045656

Lemke, J. L. (2002). Language development and identity: Multiple timescales in the social ecology of learning. In C. Kramsch (Ed.), Language Acquisition and Language Socialization, 68-87. London: Continuum.

Liguori, G. (2009). Common sense in Gramsci. In J. Francese (Ed.), Perspectives on Gramsci: Politics, Culture and Social Theory, 122-133. London: Routledge.

Marx, K. (1844). Economic and philosophic manuscripts of 1844.

Scollon, R. and Scollon, S. W. (2004). Nexus Analysis: Discourse and the Emerging Internet. New York: Routledge. https://doi.org/10.4324/9780203694343

Sennett, R. (2006). The Culture of the New Capitalism. New Haven, CT: Yale University Press.

Thomas, P. D. (2015). Gramsci's Marxism: The 'philosophy of praxis'. In M. McNally (Ed.), Antonio Gramsci, 97-117. London: Palgrave Macmillan. https://doi.org/10.1057/9781137334183_6 
Tomlinson, M. (2017). Introduction: Imagining the monologic. In M. Tomlinson and J. Millie (Eds), The Monologic Imagination, 1-18. New York: Oxford University Press. https://doi.org/10.1093/acprof:oso/9780190652807.001.0001

Vološinov, V. N. (1973). Marxism and the Philosophy of Language (L. Matejka and I. R. Titunik, Trans.). Cambridge, MA: Harvard University Press. (Original work published 1929.)

Williams, R. (1977). Marxism and Literature. Oxford: Oxford University Press.

Wolff, R. (2012). Democracy at Work: A Cure for Capitalism. Chicago, IL: Haymarket Books.

Wolff, R. D. (2015, May 26). Critics of capitalism must include its definition. Truthout. Retrieved from http://www.truth-out.org/news/ item/30678-critics-of-capitalism-must-include-its-definition\# 